\section{Notes on Contributors}

Danijela S. Beard is an Associate Lecturer in Music at Cardiff University. Her publications include Made in Yugoslavia: Studies in Popular Music (co-edited with Ljerka V. Rasmussen, in press), and several chapters on music and politics in southeast Europe/western Balkans.

Harriet Boyd-Bennett is Assistant Professor of Music at the University of Nottingham, UK. Her first book, Opera in Postwar Venice: Cultural Politics and the Avant-Garde, was recently published with Cambridge University Press (2018). She is now working on a book about music tours in Italy during the 1920s.

Martin Brady is a Lecturer in the German and Film Studies Departments at King's College London. He has published on European film (especially GDR, Brechtian and documentary cinema), music (Arnold Schönberg, Paul Dessau), philosophy, literature (including Bertolt Brecht, Franz Kafka and Elfriede Jelinek), Jewish exile architects, the visual arts (Joseph Beuys, Anselm Kiefer), disability, foraging and ordinariness. With Joanne Leal he published a monograph on the collaborative films of Wim Wenders and Peter Handke. He has translated Victor Klemperer's LTI, Alexander Kluge's Cinema Stories (with Helen Hughes) and works as an interpreter for German-speaking filmmakers. He is also active as an artist.

Eric Drott is Associate Professor of Music Theory at the University of Texas at Austin. He is author of Music and the Elusive Revolution: Cultural Politics and Political Culture in France, 1968-1981 (University of California Press, 2011). Current projects include The Oxford Handbook of Protest Music, co-edited with Noriko Manabe, and a book on music-streaming platforms.

Pauline Fairclough is Professor of Music at the University of Bristol. She has published extensively on Shostakovich and Soviet musical culture under Stalin. Her last book, Classics for the Masses: Shaping Soviet Musical Identity Under Lenin and Stalin (Yale University Press, 2016) was co-winner of the Women's Forum Book Prize of the British Association of Slavonic and East European Studies in 2017. Her biography of Dmitri Shostakovich will be published in Reaktion Press's 'Critical Lives' series in 2019.

Simon Frith is Emeritus Professor of Music at the University of Edinburgh, where he held the Tovey Chair from 2005 to 2017. A collection of his essays, Taking
Popular Music Seriously, was published in the Ashgate series 'Contemporary Thinkers on Critical Musicology' in 2007. He is presently working on a three-volume history of live music in Britain. Volume 1, covering 1950-67, was published by Ashgate in 2013. Volume 2, covering 1968-84 will be published in 2019.

Stephan Hammel is Assistant Professor of Music at the University of California, Irvine where he lectures on a variety of subjects from Latin American modernism to music and philosophy. His research focuses on developing a materialist approach to music history.

Sarah Hill is a Senior Lecturer in the School of Music at Cardiff University and Co-ordinating Editor of Popular Music. Her work has mainly concerned issues of identity and popular music, particularly in Welsh-language culture and in the historiography of popular music. Her current research project is a study of rock criticism, second-wave feminism and the curation of taste in 1970s women's magazines.

Elaine Kelly is a Senior Lecturer in Music at the University of Edinburgh. Her publications include Composing the Canon in the German Democratic Republic: Narratives of Nineteenth-Century Music (Oxford University Press, 2014), and Art Outside the Lines: New Perspectives on GDR Art Culture (Rodopi, 2011), which she edited with Amy Wlodarski.

Benjamin Piekut is an Associate Professor of Musicology at Cornell University. He is the author of Experimentalism Otherwise: The New York Avant-garde and its Limits (California University Press, 2011), and Henry Cow: The World Is a Problem (Duke University Press, in press).

Toby Thacker is Senior Lecturer at Cardiff University. He has researched the politics of music in Germany after 1945, and in the early years of the German Democratic Republic. His publications include Music After Hitler (2007), Joseph Goebbels: Life and Death (2009), and British Culture and the First World War: Experience, Representation, and Memory (2014).

Tara Wilson is a British independent scholar, having completed a $\mathrm{PhD}$ in Russian post-minimalist music at the Centre for Russian Music, Goldsmiths College, University of London, in 2015. Her research specialisms include Russian and post-Soviet music, theory and analysis, notably in relation to post-structuralist methods, and music semiotics. The author of several publications in Europe and Russia, she currently works and resides in Moscow. 